\title{
PROFILE: NICOLAS HODGES
}

Nicolas Hodges is a pianist with a wide repertoire, and has been deeply involved in contemporary music since an early age. He has given countless premieres, and has become especially closely associated with the piano concertos of Elliott Carter, Beat Furrer and Thomas Adès. Recent premieres include concerti written especially for him by Hugues Dufourt, Pascal Dusapin, Rebecca Saunders, and Miroslav Srnka.

As a concerto soloist, Nicolas's past and imminent engagements include performances with orchestras such as the Boston Symphony, Chicago Symphony,

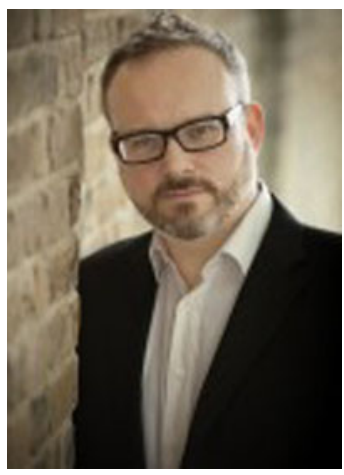

[photo: Eric Richmond] Berliner Philharmoniker, BBC Symphony,

Sinfonieorchester des Bayerischen Rundfunks, Tokyo Philharmonic and Melbourne Symphony, amongst others. He has collaborated with distinguished conductors Thomas Adès, Marin Alsop, Daniel Barenboim, George Benjamin, Tadaaki Otaka, Jukka-Pekka Saraste and Leonard Slatkin.

As a recitalist, he has performed at the most prestigious venues, such as Carnegie Hall, the Berlin Philharmonie and Wigmore Hall, and has appeared at many festivals including the BBC Proms, Salzburg Festival, Lucerne Festival, Melbourne International Arts Festival and Tanglewood. In chamber music Nicolas collaborates regularly with the Arditti Quartet, Adrian Brendel, Anssi Karttunen, Ilya Gringolts, Colin Currie and as a member of the Trio Accanto.

Q. 'New', 'contemporary', 'modern': what attracts you to 'this' music? A. I'm not attracted merely to 'new', 'contemporary' or 'modern' music, and I'm certainly not attracted to what is 'fashionable' in new music. I'm attracted to many kinds of music for many different reasons. As it happens, many of my musical interests are in contemporary music, but I am also thinking daily about Beethoven, Schoenberg, Debussy, Schumann, Bach and others.

Q. What is inspiring you at the moment?

A. The fact that I have no concerts in December so can get a lot of preparation done.

Q. Is there a project you are dreaming about creating?

A. There are always many projects floating around in my head. Many come to fruition, many do not. It's mostly a matter of time. 
Q. What current developments or trends do you perceive in new music? A. The broadening of access for young people, with regard to composition. Technology is fooling reams of young people into thinking they are composing music, when they're not. It's a catastrophe.

Q. Is the future bright for new music?

A. Yes, but only despite the above-mentioned 'composers'.

Q. What's afoot in the new music scene in Germany?

A. A million and one things, as usual. It's a remarkably open musical atmosphere. New music in Germany has just lost Armin Koehler, director of the Donaueschingen Festival. He died on 15 November, at the early age of 62 . As someone who commissioned around 400 works, most of them large-scale, he has been a huge artistic support to many composers in Germany and beyond. I am grateful to have known him for more than a decade, and thank him above all for his friendship and wisdom, as well as for enabling some great piano concerti: Rebecca Saunders' miniata, Rolf Riehm's Wer sind diese Kinder and Simon Steen-Andersen's Piano Concerto. ${ }^{1}$

Q. Who are your new music heros?

A. Composers who take risks, who challenge us, who embrace discomfort.

Q. Which five pieces of music could you not do without?

A. The next five I am to perform.

Q. How has your practice evolved over the years?

A. As time passes, one accumulates a resource of experience and innate understanding which is irreplaceable. As a young musician one believes everything in music can be understood with logic, brainpower and brilliance. But this is simply not true. The arrogance of youth, sadly, gets in the way here. I'm grateful to have two decades of work behind me and to have benefitted from my experience.

Q. What does collaboration mean to you?

A. Listening.

Q. What does 2015 hold for you?

A. On the one hand, first performances of music by James Clarke, Misato Mochizuki, Stefan Prins, Rolf Riehm, Johannes Schöllhorn, Hans Thomalla - some solo, some with Trio Accanto (my trio of saxophone, piano and percussion). On the other hand, my first public performance of a work of Mendelssohn since my childhood - the G minor Concerto, with Staatsorchester Stuttgart and Sylvain Cambreling. And everything imaginable in between! I also have CDs of Birtwistle, Ferneyhough and Walter Zimmermann about to be released, and will be recording several new ones.

\footnotetext{
1 These concerti can be heard on CD Kairos 0012762KAI (Saunders) and SACD Wergo WER 67552 (Riehm), with a CD/DVD release of the Steen-Andersen forthcoming. Each year the complete programme of the previous year's Donaueschingen festival has been published on $\mathrm{CD}$ (col legno/Neos).
} 
Q. What are you reading at the moment?

A. Paul Griffiths' The Tilted Cup, a slim collection of reimaginings of Noh stories. He's sensitive to their inner spirit.

Q. What are you hoping your legacy will be?

A. That's a wholly pretentious idea. I do my work as best I can. End of story. 